\title{
The Effect of Roots on the Shear Strength of Texturally Distinct Soils
}

\author{
Charles Maffra $^{1}$ (D), Rita Sousa ${ }^{1}$ (D), Fabrício Sutili ${ }^{1}$ (D), Rinaldo Pinheiro ${ }^{1}$ \\ ${ }^{1}$ Universidade Federal de Santa Maria - UFSM, Santa Maria/RS, Brasil
}

\begin{abstract}
The aim of this work was to evaluate the roots influence on the shear strength of a clay soil and a sandy soil. Soil samples with and without roots were collected from experimental plantations of Atlantic Forest native species. The soil samples were then physically characterized and their shear strength tested in a laboratory. The results indicated that the soils' shear strength and compressive strength were increased by the roots. In the sandy soil, roots influenced the shear strength by increasing the cohesion value (234\%), while in the clay soil they influenced the shear strength mainly by increasing the cohesion value (32\%) and the internal friction angle (14.4\%). This information can ultimately be part of the technical justifications that ratify the use of plants in erosion control and slope stabilization works.
\end{abstract}

Keywords: soil bioengineering, geotechnical engineering, rheophyte, soil-root interaction, slope stabilization. 


\section{INTRODUCTION}

The common understanding that roots play an important role in soil reinforcement has been accompanied by a growing interest in studying the mechanical strength of soil-root composites. This type of study has been shown to be important mainly because root maintenance in the soil, either through natural regeneration or with the use of specific planting techniques, is increasingly recognized as an effective, simple and economically viable method to control erosive processes and surface mass movements (Morgan \& Rickson, 1995; Gray \& Sotir, 1996; Wu et al., 2014).

Determination of soil strength is a basic requirement in slope stability studies, and is generally performed by shear strength tests. This analysis is characterized by the Mohr-Coulomb failure criterion, which is represented by the linear equation $\tau=c+\sigma_{\mathrm{n}} \cdot \operatorname{tg} \phi$ (Gerscovich, 2016). By this criterion, cohesion (c) and internal friction angle $(\varphi)$ of the soil are the parameters that can be influenced by the roots.

Studies with molded and laboratory-prepared soil samples indicate that shear strength due to root inclusion is mainly increased by influence on the cohesive intercept, while the internal friction angle suffers little or no change (Coppin \& Richards, 2007; Ali \& Osman, 2008). In practice, it is important to verify if this type of information tends to follow the field reality. Such consideration requires that determining the shear strength of different root-soil composites be conducted in undisturbed samples collected in situ.

In order to contribute information about the effect of plants on soil reinforcement, the present work had the objective to evaluate the influence of roots on the shear strength of a sandy soil and a clay soil.

\section{MATERIAL AND METHODS}

\subsection{Soil sample collection}

Samples of sandy and clay soil were collected in distinct regions of the state of Rio Grande do Sul.

The Red Latosol clay soil was collected in Frederico Westphalen (northern region of the state), in a 2-year-old experimental plantation area of Phyllanthus sellowianus (Klotzsch) Müll. Arg. and Gymnanthes schottiania Müll. Arg. The sandy colluvium soil was collected in São João do Polêsine (center of the state), in a 1-year-old experimental plantation area of Phyllanthus sellowianus.

In the mentioned areas, undisturbed soil samples with roots were collected through $20 \mathrm{~cm}$ long and $10 \mathrm{~cm}$ diameter metal cylinders. One of the ends of the cylinder was sharpened to facilitate penetrating it down into the soil. Inserting the cylinder into the soil was performed with a $2 \mathrm{~kg}$ metallic weight and a rod to centralize the load application (Figure 1A). Once positioned in the desired location, the cylinder
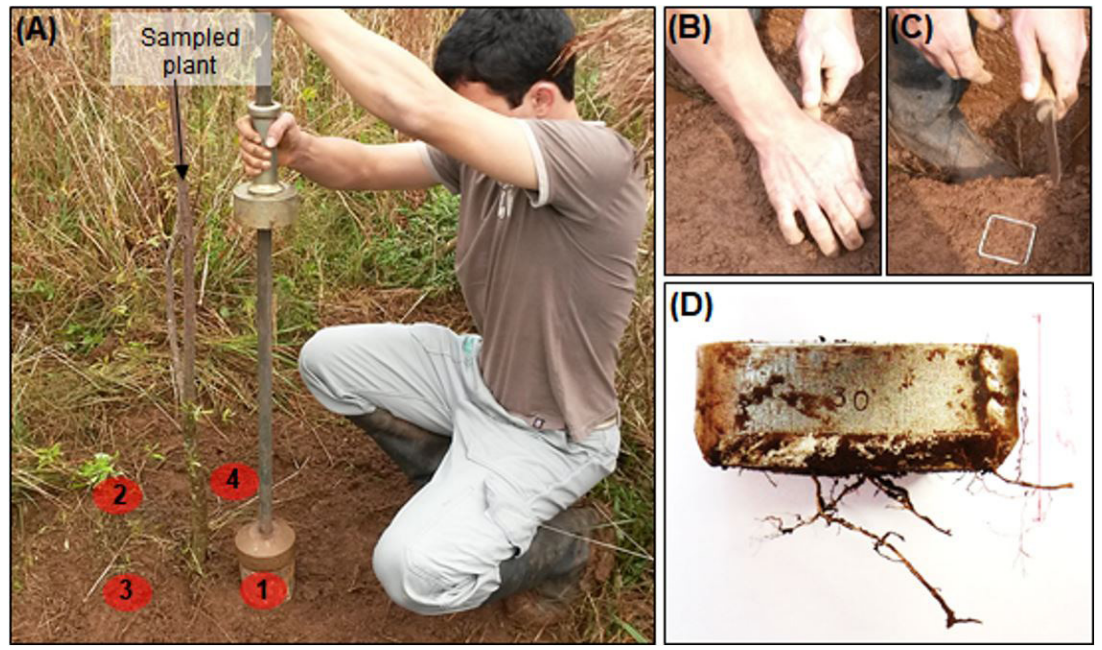

Figure 1. Collection of undisturbed samples with and without roots for direct shear tests. (A) Percussion sampler, numbers indicate sampling points around the plant; (B) and (C) sample collections without roots; (D) example of a sample with roots. 
was struck until it was completely inserted into the ground. Next, 4 points were sampled up to $20 \mathrm{~cm}$ deep in the surrounding environment of each selected plant between 10 and $20 \mathrm{~cm}$ away from the stem. After this sampling, the cylinders were removed using a shovel and hoe. In order to maintain the natural soil moisture (field moisture), the ends of the cylinders were sealed with heated paraffin. Samples with dimensions of $5 \times 5 \times 2 \mathrm{~cm}$ (Figure 1D) were prepared in the laboratory on the days of the direct shear tests from the collected cylinders. It was possible to mold 3 to 4 specimens from each collected cylinder.

The sample collections without roots were accomplished in small trenches $2.5 \mathrm{~m}$ from the plants. Once the absence of roots at the sampling points was assured, the soil was regularized with a shovel and hoe to the desired depth (between 15 and $20 \mathrm{~cm}$ ) and then the $5 \times 5 \times 2 \mathrm{~cm}$ samplers were positioned side-by-side and carefully pressed until complete insertion into the soil (Figures 1B and 1C). Once placed in the soil, the samplers were carefully extracted using a narrow blade spatula by means of small excavations on the sides and under the sample in order to ensure the integrity of the soil structure.

\subsection{Tests and analyses}

In the laboratory, $5 \times 5 \times 2 \mathrm{~cm}$ samples were prepared for direct shear tests in natural moisture (or soil moisture on the day of specimen collection). The tests were performed in a shear press and were packed fast, consisting of applying normal and horizontal forces in relation to the shear surface (ASTM, 2011). The normal stresses applied on the specimens were based on information found in the literature: 100, 200 and $300 \mathrm{kPa}$ (Silva et al., 2004; Preti \& Giadrossich, 2009; Graf et al., 2009; Moradi et al., 2017).

Four replications (shear tests) were performed for each of the normal stresses, as suggested in the Brazilian Standard of Slope Stability (ABNT, 2009). Thus, each resistance envelope was constituted by 12 test pieces, totaling 48 tests between clay soil and sandy soil, with and without roots.

The root area of the shear surface was measured after the direct shear tests. For this, each sample was divided in half (Figure 2A) and then the diameter of the roots crossing the failure surface was measured (Figure 2B). This enabled obtaining the average root rate per soil area (\%), meaning the relationship between root area and soil area (Ar/As) (Gray \& Ohashi, 1983).

For soil characterization, granulometric tests and physical index determinations were conducted such as: saturation degree $(S)$, porosity $(\eta)$, void ratio $(e)$, apparent specific natural weight $\left(\gamma_{n}\right)$, actual specific grain weight $\left(\gamma_{s}\right)$ and apparent specific dry weight $\left(\gamma_{\mathrm{d}}\right)$, taking Fiori \& Carmignani (2009) as reference.

All data obtained from field surveys and laboratory analyses were compiled and analyzed using MS Excel software.

\section{RESULTS AND DISCUSSION}

\subsection{Physical characteristics of analyzed soils}

In Table 1, it is possible to observe that the samples with and without roots presented similar average physical parameters in each type of soil evaluated.
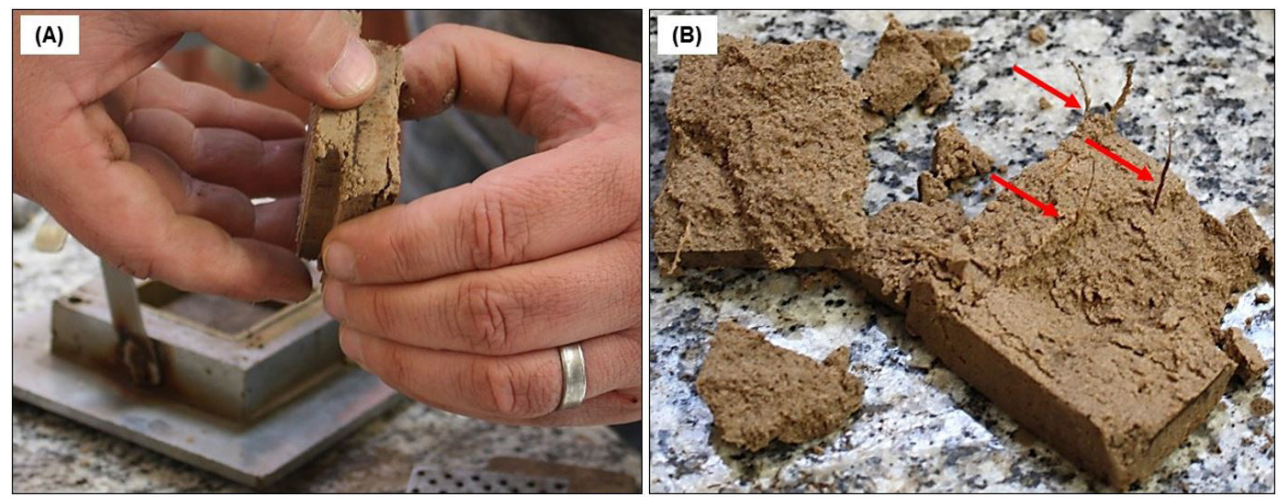

Figure 2. Sheared soil sample with roots. (A) Separating the two halves of soil sample to observe the failure surface; and (B) failure surface with perpendicular roots indicated by the arrows. 
Table 1. Average physical and textural parameters obtained from clay and sandy soils, with and without roots.

\begin{tabular}{cccccccccc} 
SOIL & $\begin{array}{c}\gamma_{\mathrm{n}} \\
\left(\mathrm{g} / \mathrm{cm}^{3}\right)\end{array}$ & $\begin{array}{c}\gamma_{\mathrm{d}} \\
\left(\mathrm{g} / \mathrm{cm}^{3}\right)\end{array}$ & $\begin{array}{c}\gamma_{\mathrm{s}} \\
\left(\mathrm{g} / \mathrm{cm}^{3}\right)\end{array}$ & $\mathrm{e}$ & $\begin{array}{c}\mathrm{S} \\
(\%)\end{array}$ & $\begin{array}{c}\text { Ar/As } \\
(\%)\end{array}$ & $\begin{array}{c}\text { Sand } \\
(\%)\end{array}$ & $\begin{array}{c}\text { Silt } \\
(\%)\end{array}$ & $\begin{array}{c}\text { Clay } \\
(\%)\end{array}$ \\
$\begin{array}{c}\text { Sandy } \\
\text { Without roots }\end{array}$ & 1.68 & 1.39 & 2.55 & 0.87 & 70.19 & & 75.0 & 18.0 & 7.0 \\
With roots & 1.87 & 1.54 & 2.55 & 0.67 & 80.88 & $0.094 \%$ & & & \\
$\quad \begin{array}{c}\text { Clay } \\
\text { Without roots }\end{array}$ & 1.74 & 1.24 & 2.75 & 1.37 & 89.27 & & 25.0 & 33.0 & 42.0 \\
With roots & 1.77 & 1.05 & 2.75 & 1.91 & 96.80 & $0.082 \%$ & & \\
\hline
\end{tabular}

$\gamma_{\mathrm{n}}=$ apparent specific natural weight of the soil; $\gamma_{\mathrm{d}}=$ apparent specific dry weight of the soil; $\gamma_{\mathrm{s}}=$ actual specific grain weight (NBR 6508/84); e = void ratio; $\mathrm{S}=$ saturation degree; $\mathrm{Ar} / \mathrm{As}=$ transversal fraction of soil area occupied by roots.

The most important differences occurred in the physical index saturation degree (S\%). The highest saturation degree values in both sandy and clay soil occurred in the samples with roots. Samples with roots in both sandy and clay soil presented about $10 \%$ more of the voids in the soil filled with water compared to the samples without roots. This difference can be attributed to the greater ease with which water penetrates the soil through the soil-root interface. The effect of decrease in water content in the soil generally results in an exponential increase of its mechanical resistance (Fredlund \& Rahardjo, 1993; Coppin \& Richards, 2007). Thus, it is expected that soils with roots have a portion of their reduced resistance precisely due to water easily infiltrating the soil. However, from the perspective of shear strength, it is possible that this effect is compensated by the mechanical resistance of the roots (Wu, 2013).

Saturation degree values were generally always higher than $70 \%$, thus indicating very humid soils; a condition that decreases the amount of resistance attributed to matric suction, which is generally expected in unsaturated soils (Fredlund \& Rahardjo, 1993). In this case, this means that the greatest portion of shear strength in a soil with roots is due to the tensile strength of these living elements (Gray \& Sotir, 1996; $\mathrm{Wu}, 2013)$.

In addition to the higher saturation degree, sandy soil and clay soil samples with roots had a mean area of roots at the failure surface of $0.094 \%$ and $0.082 \%$, respectively. Similar work has indicated that the root area percentage at the failure surface is usually less than $1 \%$ when working with individual plants (Bischetti et al., 2005; Mattia et al., 2005; Schmidt et al., 2001; Abernethy \& Rutherfurd, 2001). However, the values can reach approximately $5 \%$ when observing the contribution of a set of plants (Liang et al., 2017; Eab et al., 2015).

\subsection{Effect of roots on shear strength}

\subsubsection{Sandy soil}

The comparison between failure envelopes shows that the cohesion values (cohesive intercept) and internal friction angle of the soil (angular coefficient) were higher in the samples with roots (Figure 3 ).

The average cohesion value in the soil without roots was $6.4 \mathrm{kPa}$, while the soil with roots had an average value of $21.4 \mathrm{kPa}$. The difference between these values is $15.0 \mathrm{kPa}$. In relative terms it represents that the presence of roots in the soil contributed to increase the shear strength by $234 \%$.

The average value of the internal friction angle in the soil without roots was $27.38^{\circ}$, while in the soil with roots it was $29.01^{\circ}$. The difference between values is $1.63^{\circ}$. In relative terms this represents that the roots enabled an increase in the soil shear strength of 5.9\% by means of the internal friction angle.

The sandy soil strength parameter values followed the trend described in the literature, meaning that the major contribution of the roots to shear strength is mainly due to increases in the cohesive intercept (Waldron, 1977; Gray \& Ohashi, 1983; Shewbridge \& Sitar, 1989; Wu \& Watson, 1998; Veylon et al., 2015). This result has been attributed to the small natural cohesion of granular soils. From the mechanical reinforcement point of view, there is a tendency for the roots to contribute more to the soil shear strength when it presents high moisture content (Coppin \& Richards, 2007); the condition presented by the test specimens.

The internal friction angle of the sandy soil underwent a small change because of the roots. Studies have indicated that soil particles tend to undergo minor rearrangement due to roots (Ali \& Osman, 2008; Veylon et al., 2015). This may be associated with 


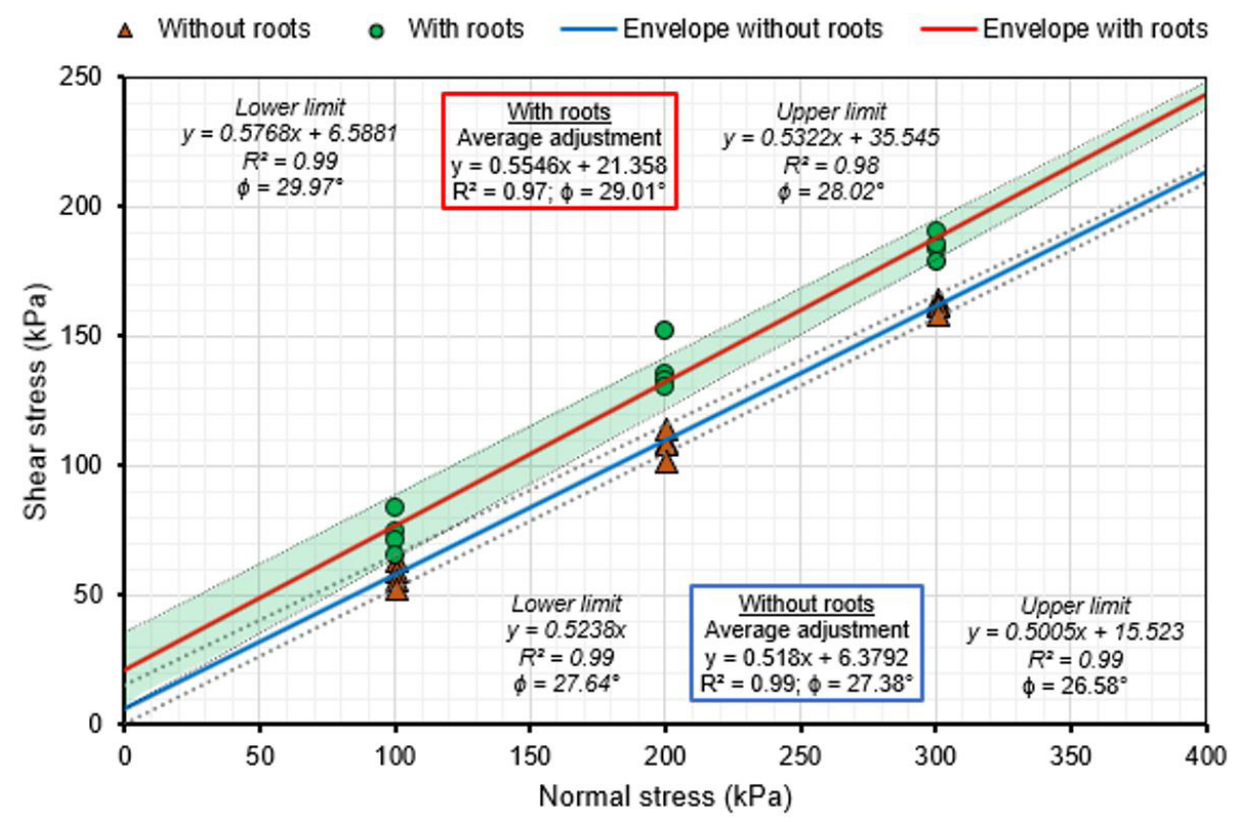

Figure 3. Failure envelopes of sandy soil with and without roots. The shaded area (soil with roots) and the dotted lines (soil without roots) represent the confidence intervals at 95\% reliability.

the small amount of roots that are normally found on the failure surface. In the more superficial layers of the soil (up to $50 \mathrm{~cm}$ ), where the root occurrence percentage is higher (Jackson et al., 1996), the mean values reported for root rate per unit area of soil (root area ratio - RAR) have normally been lower than $1 \%$ (Bischetti et al., 2005; Mattia et al., 2005; Schmidt et al., 2001; Abernethy \& Rutherfurd, 2001), which generally means that $99 \%$ of the failure surface consists of soil. This proportion seems to explain why a soil block with few roots experiences little alteration in its particle arrangement, and consequently little influence on the internal friction angle.

On the other hand, the results showed that the small average proportion of roots on the failure surface had great influence on cohesion. This is related to how the granular soil interacts with the roots. This soil type usually has very little cohesion of its own, but works very well from the friction between particles (internal friction angle). In the failure surface, the roots tend to act as a barrier to soil particles. They may fail to rupture the fibers if their resistance is overcome by the friction strength between soil and the portion of the roots that is embedded in the soil layers above and below of the failure surface (Schwarz et al., 2010). In this case, roots tend to act as natural rods (Gray \& Sotir, 1996) that promote interconnection between different soil layers.
By means of the highlighted mechanisms, the roots' presence causes the soil deformity during the direct shear test to occur at a slower rate, which directly affects the resistance peaks, and consequently the cohesion increment.

\subsubsection{Clay soil}

In the clay soil, the comparison between failure envelopes shows that the cohesion values (cohesive intercept) and internal friction angle (angular coefficient) were also higher in samples with roots (Figure 4).

In the soil without roots, the average cohesion value was $7.2 \mathrm{kPa}$, whereas in the soil with roots it was $9.6 \mathrm{kPa}$. Therefore, the roots contribution was $2.4 \mathrm{kPa}$, which corresponds to a $32 \%$ increase in the soil shear strength.

The average internal friction angle value in the soil without roots was $27.9^{\circ}$, while in the soil with roots it was $31.9^{\circ}$. The difference is $4.0^{\circ}$, corresponding to an increase of $14.4 \%$ in the soil shear strength due to the roots.

As indicated, the increase in the clay soil shear strength due to the presence of roots occurred by relatively balanced increases in cohesion values and internal friction angle. However, once again, the cohesion parameter was most influenced by the presence of roots. 


\section{$\Delta$ Without roots o With roots - Envelope without roots - Envelope with roots}

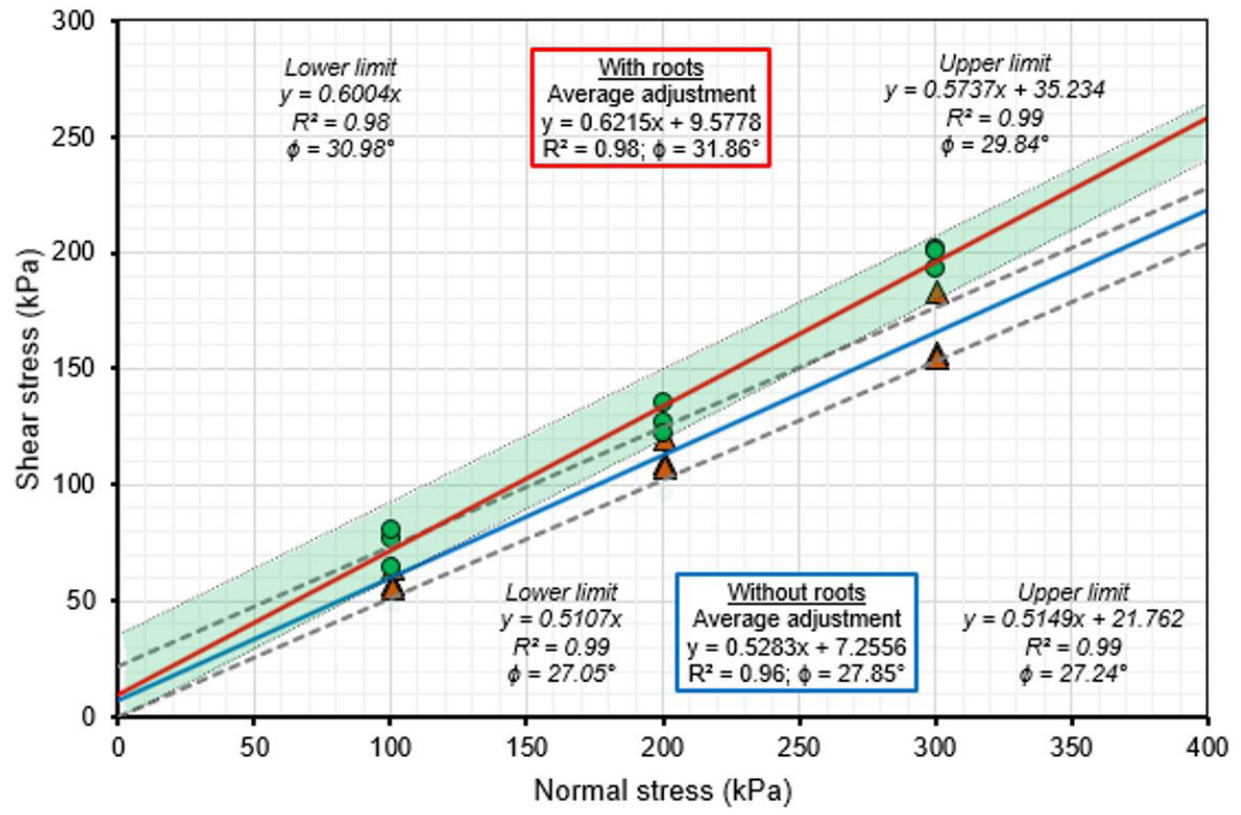

Figure 4. Failure envelopes of clay soil with and without roots. The shaded area (soil with roots) and the dotted lines (soil without roots) represent the confidence intervals at $95 \%$ reliability.

Generally speaking, the obtained results were in agreement with those observed by Moradi et al. (2017), who worked with sandy-clay composites enriched by propylene fibers. The authors pointed out that synthetic fibers (mimicking roots) added and distributed randomly in the test specimens provided considerable increases in soil shear strength, which resulted from both increases in cohesion and increases in the internal friction angle. In turn, this is something similar to what was portrayed by Jiang et al. (2010) in a work developed using clay soil reinforced by random distribution of polypropylene fibers with 0.02 to $0.05 \mathrm{~mm}$ in diameter, and a proportion of up to $4 \%$ of the test specimen weight.

\subsection{Considerations of the roots effect on resistance parameters}

As previously observed, the presence of roots in both sandy and clay soil provided increases in shear strength of the test specimens, mainly by increases in the cohesion parameter. These results are in agreement with what has been observed by different authors, both in granular soils and in fine soils, using plant roots as reinforcing elements (Waldron, 1977; Shewbridge \& Sitar, 1989; Wu \& Watson, 1998; Operstein \& Frydman,
2000; Coppin \& Richards, 2007; Stokes et al., 2008), natural fibers (coconut, sisal and jute, for example) (Gray \& Ohashi, 1983; Prabakar \& Sridhar, 2002; Ahmad et al., 2010) and/or synthetic fibers (polypropylene, polyethylene and nylon, for example) (Gray \& Ohashi, 1983; Abdullah et al., 2011; Hejazi et al., 2015).

With respect to the effects on cohesion, it can be indicated that increases in the value of this parameter should be expected whenever the roots cross the failure surface (Wu et al., 1979). On the shear surface, the plants roots can undergo rupture or slip when subjected to a shear force (Schwarz et al., 2010). The more resistant the roots are to these two failure modes, the more they contribute as soil reinforcement elements. In practice, this means that the more embedded the plant roots are below a failure surface, the greater its potential to avoid movement in the upper soil layer, as it adds resistance to a mechanically weaker layer (Wu et al., 1988; Greenwood, 2006).

In relation to the roots influence on the soil's internal angle, it is important to consider that granular soils and fine soils have different particle rearrangement forms when subjected to stresses (be these shearing or normal). Thus, for a set of roots to change the internal friction angle of a soil, it is necessary to considerably 
modify the particle arrangement in the shear surface. This can be realized with the presence of many roots or even the way they are distributed near and/or on the failure surface (Gray \& Ohashi, 1983; Veylon et al., 2015). Regarding the amount of reinforcing elements even in studies with composite materials in which several fiber types are added to the soil to test their effect on shear strength, more than $3 \%$ of the test body weight is not usually applied in random distribution (Yetimoglu \& Salbas, 2003; Prabakar \& Sridhar, 2002; Qu et al., 2013; Kar et al., 2014; Soundara \& Senthil Kumar, 2015). This is because there seems to be an optimal fiber inclusion limit for each type of soil (Kumar et al., 1999; Pradhan et al., 2012).

\subsection{Effect of roots on horizontal and vertical deformation of studied soils}

\subsubsection{Sandy soil}

As observed in the envelopes presented in Figure 3, the presence of roots had a positive effect on the sandy soil's shear strength. Similar conclusions can be drawn from the relationship between shear stress and horizontal displacement (Figures 5A and 5C), where comparisons between soil with and without roots were performed in horizontal deformations of $4 \%$ and $10 \%$.

The shear stresses in the test specimens with and without roots increased along with the horizontal deformation values. The majority of resistance peaks only occurred at the end of the direct shear tests, indicating a characteristic behavior of soft or non-compacted soil (Gerscovich, 2016).

In the three normal stresses applied in the direct shear tests $(100,200$ and $300 \mathrm{kPa})$, the specimens with roots had the highest shear stress values (comparison between Figures 5A and 5C).

Considering the $4 \%$ horizontal deformation, the specimens with roots presented an average of $24.3 \mathrm{kPa}$ more resistance than the test specimens without roots. In the $10 \%$ horizontal deformation, the mean was raised to $26.7 \mathrm{kPa}$. In relative terms, this means that the roots gave the sandy soil the ability to withstand shear stresses $35.1 \%\left(\varepsilon_{\mathrm{h}}=4 \%\right)$ and $29.2 \%\left(\varepsilon_{\mathrm{h}}=10 \%\right)$ higher than those supported by sandy soil without roots.

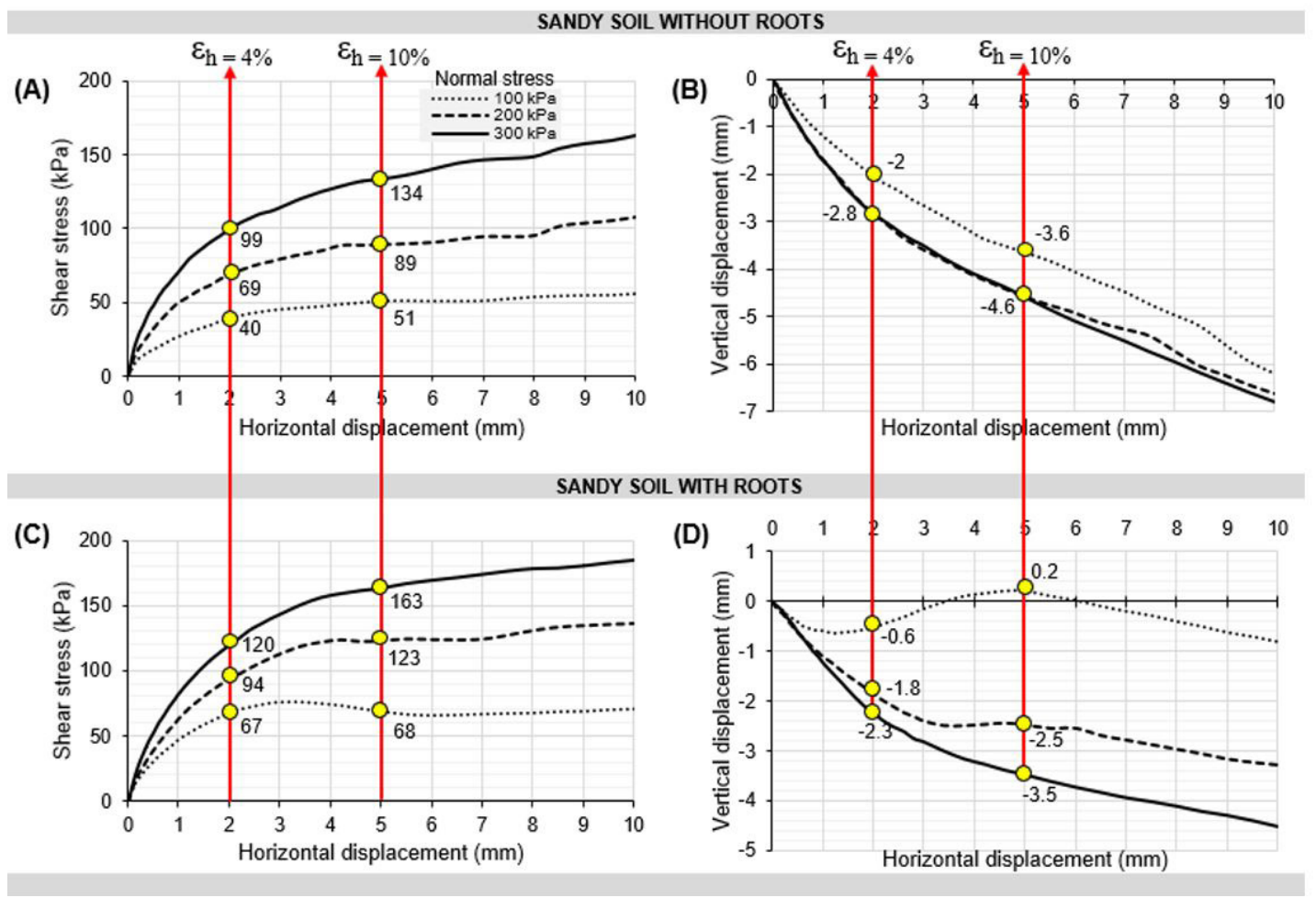

Figure 5. Average results of the relations between shear stress $\times$ horizontal displacement and vertical displacement $\times$ horizontal displacement in direct shear tests in sandy soil with $(C$ and $D)$ and without roots $(A$ and $B) . \varepsilon_{h}$ is the horizontal deformation of the soil sample (\%). 
The vertical soil deformation was also positively influenced by the presence of roots. This is verified by observing the results presented in Figures 5B and 5D. In comparing the lower normal stress applied to the test specimens in these Figures, in the case of $100 \mathrm{kPa}$ it is possible to observe that while the compression deformation increases with the increase of the horizontal deformation in the soil without roots, the compression suffers positive inflection at 3\% horizontal deformation in the soil with roots. From this value, the body begins to expand, indicating that the presence of roots promotes a redistribution of applied horizontal stresses, and consequently a rearrangement of solid particles in the shear zone. The barrier effect to the horizontal force promoted by the roots is overcome by the change in the direction in which the soil particle movement occurs, necessarily being the one that offers the least resistance.

At lower normal stresses of up to $100 \mathrm{kPa}$, the presence of roots in the soil showed to be efficient in controlling the vertical deformations (Figures 5B and 5D). On the other hand, the vertical deformations increased considerably above $100 \mathrm{kPa}$ in the soils with roots. Still, they remained below the values presented in the soils without roots.

In Figure 5D, it is also noted that the soil with roots undergoes compression at the normal stress of $100 \mathrm{kPa}$ at $10 \%$ horizontal deformation; an indication that the roots at the shear surface may have ruptured by overcoming the tensile strength or overcoming the friction resistance with soil (Stokes et al., 2008; Schwarz et al., 2010). In addition, the results obtained in this study are similar to those reported in the literature. The occurrence of one of these failure types can result in particle rearrangement, since the soil area over which the roots have influence is modified according to the test result (horizontal deformation)

\subsubsection{Clay soil}

From the three normal stresses applied in the direct shear tests, the specimens with roots also presented the highest shear stress values (comparison between Figures $6 \mathrm{~A}$ and $6 \mathrm{C}$ ).

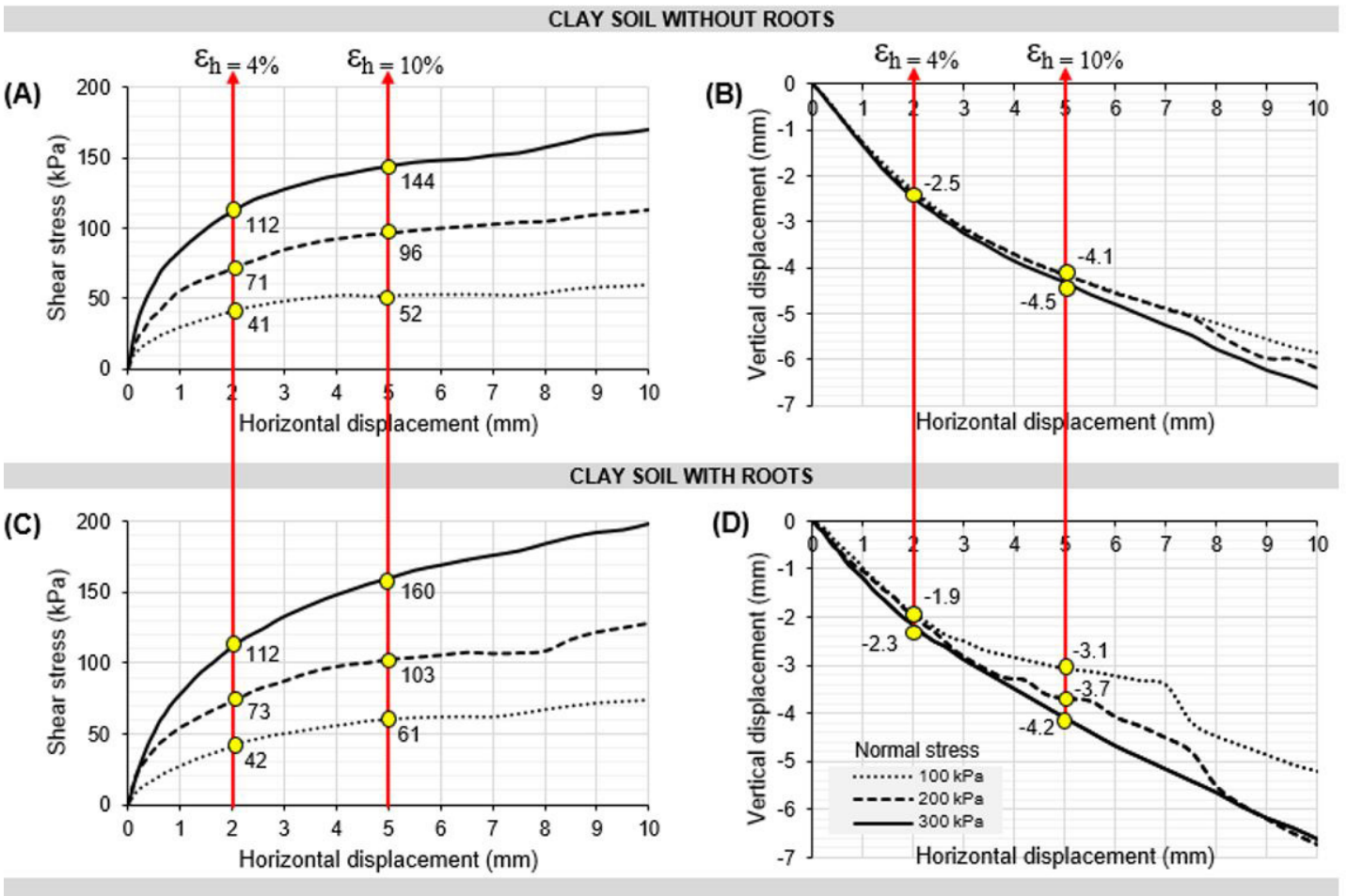

Figure 6. Average results of the relations between shear stress $\times$ horizontal displacement and vertical displacement $\times$ horizontal displacement in direct shear tests in clay soil with $(\mathrm{C}$ and $\mathrm{D})$ and without roots $(\mathrm{A}$ and $\mathrm{B}) . \varepsilon_{\mathrm{h}}$ is the horizontal deformation of the soil sample (\%). 
Considering the $4 \%$ horizontal deformation, the specimens with roots had an average of $1.0 \mathrm{kPa}$ more resistance than the test specimens without roots. In the $10 \%$ horizontal deformation, the same mean was raised to $10.7 \mathrm{kPa}$. In relative terms, this means that the roots gave the clay soil the ability to withstand shear stresses $1.3 \%\left(\varepsilon_{\mathrm{h}}=4 \%\right)$ and $10.9 \%\left(\varepsilon_{\mathrm{h}}=10 \%\right)$ higher than those supported by the clay soil without roots. Here, it is important to note that unlike sandy soil, which works well for frictional resistance, clay soil is mainly composed of fine material, and can easily rearrange around the roots when subject to a shear stress, sliding its surface in the case of a high saturation degree. In fact, water plays an important role in lubricating the interface between the fibers (roots) and the soil (Li et al., 2014). This may have been the reason for the relatively lower root contribution values occurring in support to the shear stresses, because the clay soil with roots had a saturation degree of $96.8 \%$ (Table 1), meaning with almost all the soil voids being filled by water.

The vertical soil deformation was positively influenced by the presence of roots. This is verified by observing the results presented in Figures 6B and 6D. Comparing the lower normal stress applied to the test specimens in these Figures, in the case of $100 \mathrm{kPa}$ it is possible to observe that while the compression deformation increases with the horizontal deformation increase in the soil without roots, the compression is about $24 \%$ less between horizontal deformations of $4 \%$ and $10 \%$ in the soil with roots.

Observing Figure 6B, it is possible to notice a similarity between the curves of the three normal applied stresses (100, 200 and $300 \mathrm{kPa})$, showing that the vertical deformation may have reached a limit without reinforcing elements to increase the compressive strength.

Also in Figure 6D, it is possible to infer that the roots in the clay soil show efficiency in controlling deformations coming from smaller normal tensions, in this case represented by $100 \mathrm{kPa}$. Furthermore, the roots in the higher tensions of 200 and $300 \mathrm{kPa}$ also contributed to reducing the vertical deformation by compression, but in a less expressive way. These results are in agreement with the work of Moradi et al. (2017), who observed smaller compression deformations in a sandy-clay soil composite reinforced with propylene fibers.

In the discussion of the results found for clay soil, it is worth noting the comparison between natural reinforcement (roots) and synthetic elements (which mimic roots) was made relevant. This was necessary due to the scarcity of studies that address the effects of plant root systems on shear strength, as well as horizontal and volumetric deformation of clay soils. Sandy soils are generally chosen in these types of studies because they have a less complex structure, which makes it easier to isolate the effects from including fibers.

\section{CONCLUSION}

The roots contributed to an increase in the shear strength of both the sandy soil and the clay soil. Both soils had improved shear strength by direct increases in the values of resistance parameters (cohesion and internal friction angle of the soil).

The shear strength in the sandy soil was mainly influenced by the increase in cohesion, while the shear strength in the clay soil was influenced by both the increase in cohesion (in a greater proportion) and the internal friction angle (in a smaller proportion).

Soils with roots underwent smaller deformation by compression, indicating that the plants also increase the soil's capacity to withstand vertical stresses.

The roots provided relatively higher reinforcement to the sandy soil, which was attributed to its low natural cohesion, being a direct result of its granular characteristic.

The obtained information is analytically indicative of how the roots act in reinforcing soils. This information may ultimately form part of the technical justifications that ratify the use of plants to control erosion processes and slope stabilization.

\section{SUBMISSION STATUS}

Received: 7 oct., 2017

Accepted: 6 june, 2018

\section{CORRESPONDENCE TO}

\section{Charles Maffra}

Laboratório de Engenharia Natural - LabEN, Universidade Federal de Santa Maria - UFSM, Av. Roraima, 1000, Prédio 44N, CEP 97110-210, Santa Maria, RS, Brasil

e-mail: charles.maffra@gmail.com 


\section{REFERENCES}

Abdullah MN, Osman N, Ali FH. Soil-root shear strength properties of some slope plants. Sains Malaysiana 2011; 40(10): 1065-1073.

Abernethy B, Rutherfurd ID. The distribution and strength of riparian tree roots in relation to riverbank reinforcement. Hydrological Processes 2001; 15(1): 63-79. http://dx.doi. org/10.1002/hyp.152.

Ahmad F, Bateni F, Azmi M. Performance evaluation of silty sand reinforced with fibres. Geotextiles and Geomembranes 2010; 28(1): 93-99. http://dx.doi. org/10.1016/j.geotexmem.2009.09.017.

Ali FH, Osman N. Shear strength of a soil containing vegetation roots. Soil and Foundation 2008; 48(4): 587596. http://dx.doi.org/10.3208/sandf.48.587.

American Society for Testing and Materials - ASTM. D3080/D3080M: standard method for direct shear test of soils under consolidated drained conditions. West Conshohocken: ASTM; 2011.

Associação Brasileira de Normas Técnicas - ABNT. NBR 11682: estabilidade de taludes. Rio de Janeiro: ABNT; 2009.

Bischetti GB, Chiaradia EA, Simonato T, Speziali B, Vitali B, Vullo $\mathrm{P}$ et al. Root strength and root area ratio of forests species in Lombardy (Northern Italy). Plant and Soil 2005; 278(1): 11-22. http://dx.doi.org/10.1007/ s11104-005-0605-4.

Coppin NJ, Richards IJ. Use of vegetation in civil engineering. 2nd ed. London: Construction Industry Research and Information Association; 2007.

Eab KH, Likitlersuang S, Takahashi A. Laboratory and modelling investigation of root-reinforced system for slope stabilisation. Soil and Foundation 2015; 55(5): 1270-1281. http://dx.doi.org/10.1016/j.sandf.2015.09.025.

Fiori AP, Carmignani L. Fundamentos de mecânica dos solos e das rochas: aplicações na estabilidade de taludes. 2. ed. Curitiba: UFPR; 2009.

Fredlund DG, Rahardjo H. Soil mechanics for unsaturated soils. New York: John Wiley \& Sons; 1993. 544 p. http:// dx.doi.org/10.1002/9780470172759.

Gerscovich DMS. Estabilidade de Taludes. 2. ed. São Paulo: Oficina de Textos; 2016.

Graf F, Frei M, Böll A. Effects of vegetation on the angle of internal friction of a moraine. Forest Snow and Landscape Research. 2009; 82(1): 61-77.

Gray DH, Ohashi H. Mechanics of fiber reinforcement in sand. Journal of Geotechnical Engineering 1983; 109(3): 335-353. http://dx.doi.org/10.1061/(ASCE)07339410(1983)109:3(335).

Gray DH, Sotir RB. Biotechnical and soil bioengineering slope stabilization: a practical guide for erosion control. 1st ed. New York: Wiley \& Sons; 1996.
Greenwood JR. SLIP4EX: a program for routine slope stability analysis to include the effects of vegetation, reinforcement and hydrological changes. Geotechnical and Geological Engineering 2006; 24(3): 449-465. http:// dx.doi.org/10.1007/s10706-005-4156-5.

Hejazi SM, Baghulizadeh AR, Nateghi M, Mardani M. Shear modeling of polypropylene-fiber-reinforced soil composite using electrical conductivity contour technique. Journal of Industrial Textiles 2015; 45(1): 133-151. http:// dx.doi.org/10.1177/1528083714528014.

Jackson RB, Canadell J, Ehleringer JR, Mooney HA, Sala OE, Schulze ED. A global analysis of root distributions for terrestrial biomes. Oecologia 1996; 108(3): 389-411. http://dx.doi.org/10.1007/BF00333714. PMid:28307854.

Jiang H, Cai Y, Liu J. Engineering properties of soils reinforced by short discrete polypropylene fiber. Journal of Materials in Civil Engineering 2010; 22(12): 1315-1322. http://dx.doi.org/10.1061/(ASCE)MT.1943-5533.0000129.

Kar RK, Pradhan PK, Naik A. Effect of randomly distributed coir fibers on strength characteristics of cohesive soil. The Electronic Journal of Geotechnical Engineering 2014; 19: 1567-1583.

Kumar R, Kanaujia VK, Chandra D. Engineering behavior of fibre-reinforced pond ash and silty sand. Geosynthetics International 1999; 6(6): 509-518. http://dx.doi.org/10.1680/ gein.6.0162.

Li J, Tang C, Wang D, Pei X, Shi B. Effect of discrete fibre reinforcement on soil tensile strength. Journal of Rock Mechanics and Geotechnical Engineering 2014; 6(2): 133-137. http://dx.doi.org/10.1016/j.jrmge.2014.01.003.

Liang T, Knappett JA, Bengough AG, Ke YX. Smallscale modelling of plant root systems using 3D printing, with applications to investigate the role of vegetation on earthquake-induced landslides. Landslides 2017; 14(5): 1747-1765. http://dx.doi.org/10.1007/s10346-017-0802-2.

Mattia C, Bischetti GB, Gentile F. Biotechnical characteristics of root systems of typical Mediterranean species. Plant and Soil 2005; 278(1): 23-32. http://dx.doi.org/10.1007/ s11104-005-7930-5.

Moradi M, Hamidi A, Tavakoli Mehrjardi G. Shear strength of fiber-reinforced clay sands. Journal of Engineering Geology 2017; 10(4):3767-3792. http://dx.doi.org/10.18869/ acadpub.jeg.10.4.3767.

Morgan RPC, Rickson RJ. Slope stabilization and erosion control: a bioengineering approach. London: E \& FN SPON; 1995. 274 p. http://dx.doi.org/10.4324/9780203362136.

Operstein V, Frydman S. The influence of vegetation on soil strength. Ground Improvement 2000; 4(2): 81-89. http://dx.doi.org/10.1680/grim.2000.4.2.81.

Prabakar J, Sridhar RS. Effect of random inclusion of sisal fibre on strength behavior of soil. Construction \& Building Materials 2002; 16(2): 123-131. http://dx.doi. org/10.1016/S0950-0618(02)00008-9. 
Pradhan PK, Kar RK, Naik A. Effect of random inclusion of polypropylene fibers on strength characteristics of cohesive soil. Geotechnical and Geological Engineering 2012; 30(1): 15-25. http://dx.doi.org/10.1007/s10706-011-9445-6.

Preti F, Giadrossich F. Root reinforcement and slope bioengineering stabilization by Spanish Broom (Spartium junceum L.). Hydrology and Earth System Sciences 2009; 13(9): 1713-1726. http://dx.doi.org/10.5194/hess-131713-2009.

Qu J, Li C, Liu B, Chen X, Li M, Yao Z. Effect of random inclusion of wheat straw fibers on shear strength characteristics of Shanghai cohesive soil. Geotechnical and Geological Engineering 2013; 31(2): 511-518. http:// dx.doi.org/10.1007/s10706-012-9604-4.

Schmidt KM, Roering JJ, Stock JD, Dietrich WE, Montgomery $\mathrm{DR}$, Schaub T. The variability of root cohesion as an influence on shallow landslide susceptibility in the Oregon Coast Range. Canadian Geotechnical Journal 2001; 38(5): 995-1024. http://dx.doi.org/10.1139/t01-031.

Schwarz M, Preti F, Giadrossich F, Lehmann P, Or D. Quantifying the role of vegetation in slope stability: a case study in Tuscany (Italy). Ecological Engineering 2010; 36(3): 285-291. http://dx.doi.org/10.1016/j.ecoleng.2009.06.014.

Shewbridge SE, Sitar N. Deformation characteristics of reinforced sand in direct shear. Journal of Geotechnical Engineering 1989; 115(8): 1134-1147. http://dx.doi. org/10.1061/(ASCE)0733-9410(1989)115:8(1134).

Silva RB, Dias MS Jr, Santos FL, Franz CAB. . Resistência ao cisalhamento de um Latossolo sob diferentes uso e manejo. Revista Brasileira de Ciência do Solo 2004; 28(1): 165-173. http://dx.doi.org/10.1590/S0100-06832004000100016.

Soundara B, Senthil Kumar KP. Effect of fibers on properties of clay. International Journal of Engineering and Applied Sciences 2015; 2(5): 123-128.

Stokes A, Norris JE, Van Beek LPH, Bogaard T, Cammeraat E, Mickovski SB et al. How vegetation reinforces soil on slopes. In: Norris JE, Stokes A, Mickovski SB, Cammeraat
E, Van Beek R, Nicoll BC et al., editors. Slope stability and erosion control: ecotechnological solutions. Dordrecht: Springer; 2008. http://dx.doi.org/10.1007/978-1-40206676-4_4.

Veylon G, Ghestem M, Stokes A, Bernard A. Quantification of mechanical and hydric components of soil reinforcement by plant roots. Canadian Geotechnical Journal 2015; 52(11): 1-11. http://dx.doi.org/10.1139/cgj-2014-0090.

Waldron LJ. Shear resistance of root-permeated homogeneous and stratified soil. Soil Science Society of America Journal 1977; 41(5): 843-849. http://dx.doi.org/10.2136/sssaj197 $7.03615995004100050005 x$.

$\mathrm{Wu} \mathrm{TH}$. Root reinforcement of soil: review of analytical models, test results, and applications to design. Canadian Geotechnical Journal 2013; 50(3): 259-274. http://dx.doi. org/10.1139/cgj-2012-0160.

Wu TH, Kokesh CM, Trenner BR, Fox PJ. Use of live poles for stabilization of a shallow slope failure. Journal of Geotechnical and Geoenvironmental Engineering 2014; 140(10): 1-13. http://dx.doi.org/10.1061/(ASCE)GT.19435606.0001161 .

Wu TH, McKinnell WP 3rd, Swanston DN. Strength of tree roots and landslides on Prince of Wales Island, Alaska. Canadian Geotechnical Journal. 1979; 16(1): 19-33. http:// dx.doi.org/10.1139/t79-003

Wu TH, McOmber RM, Erb RT, Beal PE. Study of soilroot interaction. Journal of Geotechnical Engineering 1988; 114(12): 1351-1375. http://dx.doi.org/10.1061/ (ASCE)0733-9410(1988)114:12(1351).

Wu TH, Watson A. In-situ shear tests of soil blocks with roots. Canadian Geotechnical Journal 1998; 35(4): 579590. http://dx.doi.org/10.1139/t98-027.

Yetimoglu T, Salbas O. A study on shear strength of sands reinforced with randomly distributed discrete fibers. Geotextiles and Geomembranes 2003; 21(2): 103-110. http://dx.doi.org/10.1016/S0266-1144(03)00003-7. 